\title{
The Performance of Hydrogen Generator based on a 4/4 Al-Cu Plates Designed Sandwich
}

\author{
Rahadian Zainul and Sri Wahyu Wardani \\ Department of Chemistry, FMIPA, Universitas Negeri Padang \\ Email : rahadianzmsiphd@yahoo.com
}

\begin{abstract}
This research aims to make a 4/4 plate $\mathrm{Al}-\mathrm{Cu}$ platebased hydrogen generator. The method used is design and engineering as well as testing the performance of the gas produced during the electrolysis process of water. The results obtained are hydrogen reactors that are capable of producing $7.5 \mathrm{~mL}$ of gas from water with a supporting voltage of $2 \mathrm{~V}$ and an electric current of $0.6 \mathrm{~A}$. In sodium acetate $\left(\mathrm{CH}_{3} \mathrm{COONa}\right)$ material $144 \mathrm{~mL}$ of gas is produced at a supporting voltage of $2 \mathrm{~V}$ and an electric current of 0.6 A.
\end{abstract}

Keywords: Generator, Performance, Generator, Al-Cu, Sandwich

\section{Intoduction}

Renewable energy and uncontaminated environment are two important things nowadays. The main source of energy that has been used for vehicle fuel and industrial is fossil fuels (Jang et al., 2010). Energy produced from fossil fuels (oil, natural gas, coal) produces greenhouse gases, like carbon dioxide $(\mathrm{CO} 2)$, methane $(\mathrm{CH} 4)$ which causes global warming. The use of fossil fuels also causes harm in the human body and all creatures in the environment. Reserves of fossil resources are also limited so that renewable energy is needed (renewable energy) and also eco-friendly to overcome this problem (de Fátima Palhares et al., 2018).

One of the existing renewable energy is water energy (Novan, Yoga., 2017). Hydrogen is the focus of attention for the development of renewable energy because it is cleaner and eco-friendly (Fan et al., 2013). Hydrogen from stocking sources can be used as biofuels and its use has increased especially regarding use in fuel cells. Energy gains in $\mathrm{H} 2$ can be stored for future use so as to reduce problems arising from consumption of non-renewable resources (dos Santos et al.,2017). Hydrogen from water is one alternative energy source that can reduce dependence on fossil fuels while reducing pollution (Jang et al., 2010).

This study, it was divided into how to design hydrogen reactors that will produce gas by electrolysis. The electrolysis process is carried out by a dry electrolysis system by placing two plates close together. This system is called a sandwich or layered system. The purpose of more specific research is how the ability of sandwich-based hydrogen cells to produce hydrogen and oxygen gas as a result of the electrolysis. 


\section{Experimental Section}

\section{Tools and material}

Tools and materials were used in this research i.e., digital multimeter (heles), Power Supplay, Alumunium (0.7 $\mathrm{mm}$ thickness), copper (0.4 mm thickness), acrylic, socket, bolt 13, saw, drill, tube , rubber ( $2 \mathrm{~mm})$, tube, $\mathrm{CH}_{3} \mathrm{COONa}$ (Merck), aquadest.

\section{Procedure}

Electrode preparation

Copper plate $(0.4 \mathrm{~mm})$ and aluminum plate $(0.7 \mathrm{~mm})$ in the form of sheets are cut to a size of $10 \mathrm{~cm}$ wide and $10 \mathrm{~cm}$ long by 8 sheets. Then, the plate is holeed as the place to install the bolt and the place of the gas duct.

Prepare tools and materials in the form of reactors that are assembled with 8 electrode plates. Then, prepare a power supply that has paired cable plugs and cables with clamps. Then, prepare $\mathrm{CH}_{3} \mathrm{COONa} 0.01 \mathrm{M}$ electrolyte solution to be inserted into the electrolyte storage tube as the material to be electrolyzed. Next, prepare a measuring cup with a beaker as a measuring device for hydrogen gas volume. Insert the hose from the reactor into a measuring cup filled with water.

The scheme of the design of a sandwich-based hydrogen generator can be seen in figure 1 .

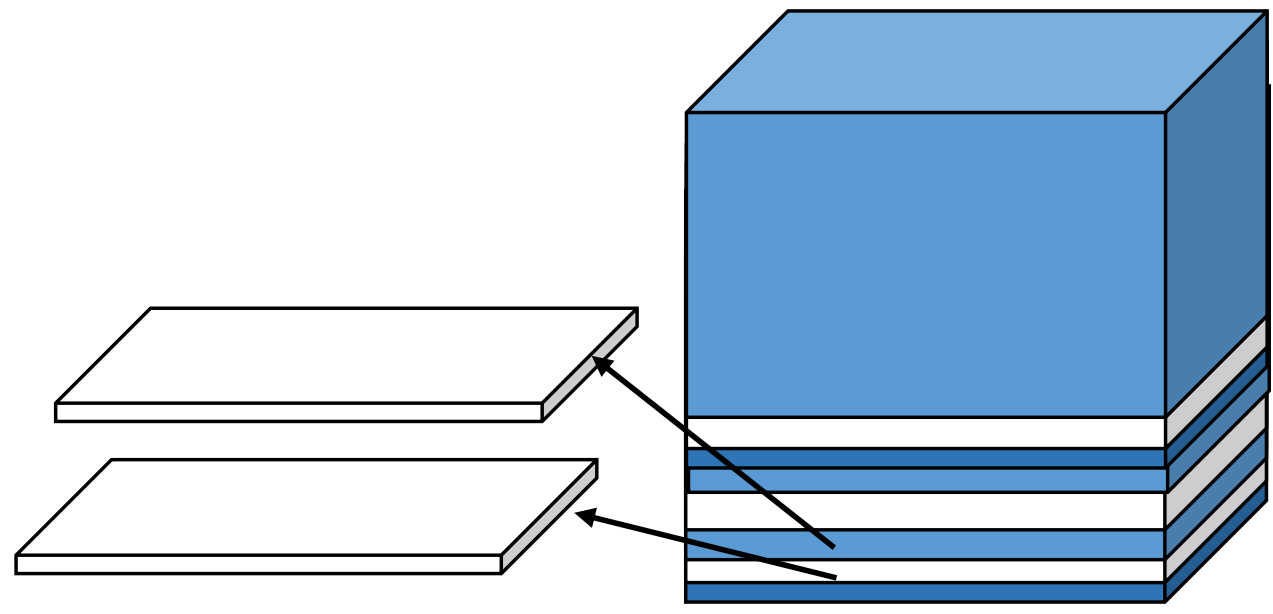

Figure 1. Hydrogen Generator Scheme with several plate (sandwich) using Copper and aluminium plates)

Furthermore, a tube containing an electrolyte solution is given a DC electric current to react to the solution so that water breaks into hydrogen and oxygen gas. When an electric current is given, hydrogen gas and oxygen will flow through the gas output hose to the measuring cup. Before the gas fills the measuring cup, record the initial volume data of the size scale on the measuring cup and after hydrogen gas and oxygen fill the measuring cup for 1 hour, it will get the final volume from the size scale on the measuring cup, note the measured data. 


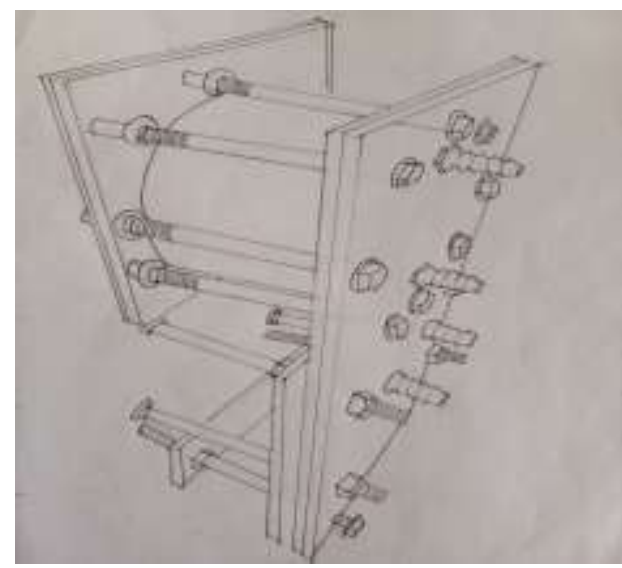

Figure 2. Design and Schematic hydrogen generator

Based on figure 2, the acryclic cover will handling the Alumunium-Copper plates like a sandwich. It will change according type of reactor, $2 \times 2$ model, $4 \times 4$ model etc. This considerly the using of plate and energy in generator. Thus, this research is $4 \times 4$ hydrogen sandwich generator will be evaluated for producing gas.

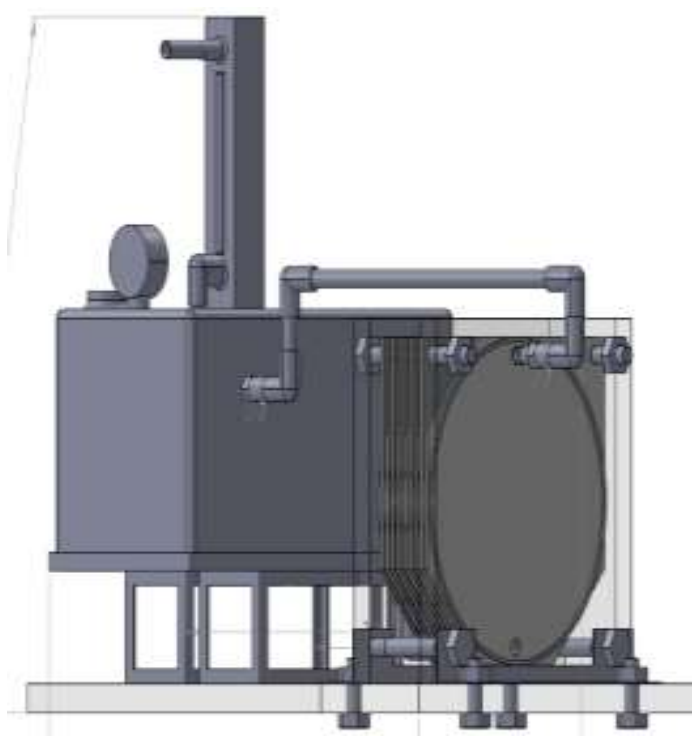

Figure 3. Complete design of hydrogen sandwich generator

The complete design of the sandwich hydrogen generator can be seen in Figure 3 . The figure illustrates a part connected to the plate and the gas flow produced during electrolysis. 


\section{Result and Discussion}

Hydrogen generators made using a plate coating system produce the shape as shown in Figure 2. The plate used in this manufacture is a $\mathrm{Cu}$ plate with a thickness of $0.4 \mathrm{~mm}$ and an aluminum plate with a thickness of $0.7 \mathrm{~mm}$. Assembling is done using the acriclic as the outer insulator of the generator. In the second plate coating system, it must be ensured that they are not connected to each other. This is because if both are connected then the function in gas production will be disrupted when electric current is flowed.

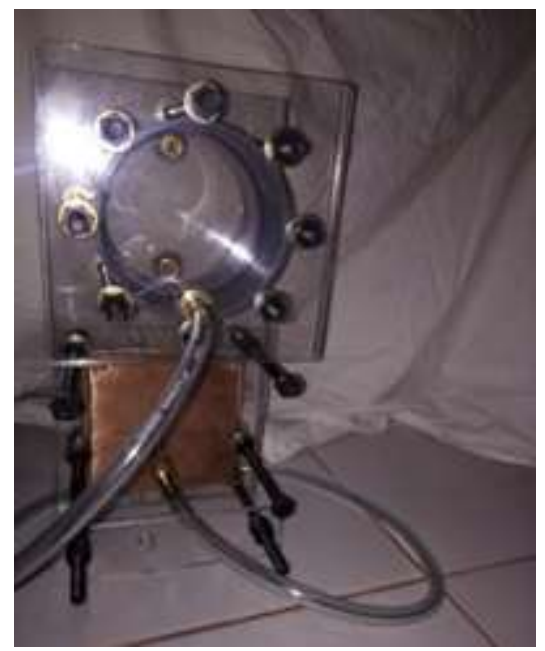

Figure 4. sandwich system generator of hydrogen with 4 x 4 Al-Cu Plates

From the results of testing the reactor for 1 hour, it turned out to produce a gas with a large enough volume, namely $7.5 \mathrm{~mL}$ and $144 \mathrm{~mL}$ each for water and CH3COONa. In testing, the reactor runs stably and the gas production process continues continuously with higher conditions of Sodium Acetate salt. This happens because in ionic conditions, the movement of ion ions is more active and maximum so the chances of oxidation and oxidation are higher.

The test results in table 1 are tests for 1 hour with the source of energy from the modified power supply. In water conditions only, there is an increase in the amount of gas that is not so significant. This is because water conditions without ionic balance occur ion ions in the system. Both $\mathrm{OH}$ and $\mathrm{H}+$ ions are in equilibrium so that when the electron enters the generator system, the gas formation process does not go well.

Table 1. Gas Production from Hydrogen generator for 1 hour

\begin{tabular}{cccc}
\hline Electrolyte & Current (A) & Voltege $(\mathbf{V})$ & $\begin{array}{c}\text { Gas Production } \\
(\mathbf{m L})\end{array}$ \\
\hline Water & 0.6 & 2 & $7.5 \mathrm{~mL}$ \\
$\mathrm{CH}_{3} \mathrm{COONa}$ & 0.6 & 2 & $144 \mathrm{~mL}$ \\
\hline
\end{tabular}

\section{Conclusion}

103 |EKSAKTA: Berkala IImiah Bidang MIPA 
From the developed generators it can be concluded that the $4 \times 4$ sandwich system with $\mathrm{Al}$ and $\mathrm{Cu}$ plates, was successfully developed in salt and water solutions. The ability of hydrogen generators to produce gas has been tested with water, with a production capability of $7.5 \mathrm{~mL}$, and in sodium acetate solution of $144 \mathrm{~mL}$, with a power of $2 \mathrm{~V}$ and $0.6 \mathrm{~A}$.

\section{References}

1. de Fátima Palhares, D. D. A., Vieira, L. G. M. and Damasceno, J. J. R. (2018) 'Hydrogen production by a low-cost electrolyzer developed through the combination of alkaline water electrolysis and solar energy use', International Journal of Hydrogen Energy, 43(9), pp. 4746-4753. doi: 10.1016/j.ijhydene.2018.01.051.

2. dos Santos, K. G. et al. (2017) 'Hydrogen production in the electrolysis of water in Brazil, a review', Renewable and Sustainable Energy Reviews. Elsevier, 68(July 2016), pp. 563-571. doi: 10.1016/j.rser.2016.09.128.

3. Fan, Wenqing., Qinghong Zhang dan Ye Wang. 2013. "Semiconductor-based Nanocomposites for Photocatalytic $\mathrm{H}_{2}$ Production and $\mathrm{CO}_{2}$ Conversion. Phys.Chem. DOI: 10.1039/C6TA10497E.

4. Jang, B. W. L. et al. (2010) 'Fuels of the future', Energy and Environmental Science, 3(3), p. 253. doi: 10.1039/c003390c.

5. Novan, Yoga. (2017). ' Pengaruh Prosentase Fraksi Massa NaOH (Natrium Hidroksida) Sebagai Katalis Dalam Proses Elektrolisis Dengan Menggunakan Elektrolizer Tipe Dry Cell'. Malang: Jurnal Islam Malang 